\title{
HUBUNGAN PEMBERIAN IMUNISASI DASAR DENGAN PERTUMBUHAN PADA BALITA (1-5 TAHUN) DI PUSKESMAS BLANG MANGAT KOTA LHOKSEUMAWE
}

\author{
Roslinawati $^{1 *}$, Rika Mursyida ${ }^{2}$, Fauziah $^{3}$ \\ 1.2.3 STIKes Bumi Persada Lhokseumawe
}

Koresponden* :

Roslinawati : Program Studi D-III Kebidanan, STIKes Bumi Persada Lhokseumawe, J1. MedanB.Aceh, Desa Alue Awe Simpang Elak Kota Lhokseumawe, email : sutan.albraza@gmail.com

\begin{abstract}
ABSTRAK
Pemberian Imunisasi dasar lengkap sangat penting pada bayi berusia 0-12 bulan untuk menumbuhkan kekebalan dari berbagai jenis penyakit yang dapat dicegah dengan pemberian imunisasi. Berdasarkan estimasi global yang di upayakan WHO (World Health Organization) pemberian imunisasi kepada bayi dapat mencegah sekitar 25 juta kematian balita tiap tahun. Untuk mengetahui apakah ada hubungan pemberian imunisasi dasar dengan pertumbuhan pada balita (1-5 tahun) Jenis penelitian ini bersifat analitik dengan desain studi cross sectional dengan jumlah 104 yang didapatkan dengan metode Slovin. Hasil dari penelitian menunjukkan sebagian besar balita memiliki riwayat imunisasi tidak lengkap yaitu 69\%. pertumbuhan balita (1-5 tahun) pada kategori gizi kurang 61\%, dari hasil uji bifariat ada hubungan secara signifikan terhadap pertumbuhan pada balita (1-5 tahun) dengan nilai signifikan $(p)$ sebesar 0.002. Disarankan kepada pihak puskesmas untuk memberikan penyuluhan secara optimal kepada ibu untuk membawa anaknya ke pelayanan Kesehatan untuk mendapatkan imunisasi.
\end{abstract}

Kata Kunci : balita, gizi buruk, imunisasi

\section{ABSTRACT}

Providing complete basic immunization is very important for infants aged 0-12 months to develop immunity from various types of diseases that can be prevented by immunization. Based on global estimates made by the WHO (World Health Organization), immunization to infants can prevent around 25 million deaths per year under five. To find out whether there is a relationship between basic immunization and growth in children under five (1-5 years). This type of research is analytic with a cross-sectional study design with a total of 104 obtained by the Slovin method.. The results of the study showed that most children under five had a history of incomplete immunization, namely 69\%. The growth of toddlers (1-5 years) in the malnutrition category is $61 \%$, from the results of the bifariate test there is a significant relationship to growth in children under five (1-5 years) with a significant value (p) of 0.002. It is recommended that the puskesmas provide optimal education to mothers to bring their children to health services to get immunizations.

Keywords: toddlers, malnutrition, immunization 


\section{PENDAHULUAN}

Kesehatan anak masih menjadi pusat perhatian penduduk di dunia. Hal ini dikuatkan dengan bukti salah satu indikator ketiga dari 17 indikator dalam Sustainable Development Goals (SDGs) yaitu pada tahun 2030, angka kematian neonatal sedikitnya 12/1000 kelahiran hidup dan angka kematian anak dibawah usia 5 tahun sedikitnya 25/1000 kelahiran hidup. Pemberian Imunisasi bertujuan untuk membuat kekebalan terhadap virus atau antigen tertentu untuk mencegah penyakit dan kematian bayi dan anak. Pernyataan yang sudah di fahami bahwa imunisasi ada hubungannya dengan malnutrisi akan berkaitan dengan penyakit infeksi yang dapat secara langsung mempengaruhi terhadap status gizi anak (Dwiastuti 2012).

Pemberian imunisasi dalam kesehatan nasional adalah salah satu bentuk perlakuan kesehatan yang sangat efektif dalam usaha menurunkan angka kematian bayi dan balita di Indonesia. Dasar utama pelayanan kesehatan dalam bidang preventif merupakan prioritas utama, dengan pemberian imunisasi terhadap seorang bayi dan balita, tidak semata-mata memberikan perlindungan pada anak, karena akan meningkatkan imunitas umum yang meningkat dan mengurangi penyebaran infeksi. Pemberian imunisasi dasar juga sangat berpengaruh terhadap proses tumbuh kembang balita. Pertumbuhan dan perkembangan pada bayi dan balita merupakan hal yang sangat penting bagi mahkluk hidup yaitu sebagai upaya untuk mempertahankan hidup dan mendapatkan keturunan yang berkwalitas (Ranuh, dkk, 2014).

Menurut Soetjiningsih (2014), pemberian imunisasi dasar lengkap yang sangat berpengaruh terhadap pertumbuhan dan perkembangan balita yaitu pemberian imunisasi polio yang bertujuan untuk mencegah terjadinya penyakit poliomyelitis pada anak yang bisa menyebabkan kelumpuhan.

Merujuk terhadap penelitian terdahulu yang dilakukan Kaunang, dkk (2016) di Puskesmas Kembes Kecamatan Tombolu Kabupaten Minahasa meneliti tentang Hubungan Pemberian Imunisasi Dasar dengan Tumbuh Kembang pada Bayi (0-1 Tahun) dengan jenis penelitian observational analitik dengan desain studi "cross sectional". Hasil penelitian menunjukkan bahwa terdapat hubungan pemberian imunisasi dasar dengan pertumbuhan bayi dengan nilai p-value 0.000 $<0.05$.

\section{METODE}

Penelitian dilakukan menggunakan desain studi cross sectional. Penelitian ini bertujuan untuk mengetahui hubungan pemberian imunisasi dasar dengan pertumbuhan pada balita (1-5 tahun) antara lain dengan masalah berat badan dan pertumbuhan. Penelitian ini dilakukan pada April 2019 di Puskesmas Blang Mangat Kota Lhokseumawe dengan jumlah sampel 104 balita, yang didapatkan melalui metode Slovin. 
Proses pengumpulan data dilakukan setelah peneliti mendapatkan izin dari Dinas Kesehatan dan kepala puskesmas. Kemudian pengambilan data dilakukan secara primer dan sekunder. Data primer diperoleh langsung dilokasi penelitian pada saat dilakukan pengukuran berat badan (BB) dan tinggi badan (TB), kemudian wawancara dilakukan dengan menggunakan kuesioner terhadap responden yang berisikan 2 pertanyaan yang berhubungan dengan variabel penelitian in, serta peneliti juga melakukanobservasi KMS untuk menilai pertumbuhan pada balita.

\section{HASIL}

Hasil penelitian ini bertujuan untuk mengetahui hubungan pemberian imunisasi dasar dengan pertumbuhan pada balita (1-5 tahun) antara lain dengan masalah pemberian imunisasi, pertumbuhan balita, dan hubungan pemberian imunisasi terhadap pertumbuhan

Tabel 1. Distriusi Frekuensi Pemberian Imunisasi Dasar di Puskesmas Blang Mangat Kota Lhokseumawe Tahun 2019

\begin{tabular}{|c|l|c|c|}
\hline No & $\begin{array}{c}\text { Pemberian } \\
\text { Imunisasi } \\
\text { Dasar }\end{array}$ & Frekuensi & $\begin{array}{c}\text { Persentase } \\
\text { (\%) }\end{array}$ \\
\hline \multirow{2}{*}{ 1. } & Lengkap & 32 & 31 \\
2. & Tidak & 72 & 69 \\
\cline { 2 - 4 } & Lengkap & & \\
\hline \multicolumn{2}{|c|}{ Total } & 104 & 100 \\
\hline
\end{tabular}

Tabel 1 menunjukkan bahwa pemberian imunisasi dasar di Puskesmas Blang Mangta Kota Lhokseumawe tahun
2019, sebagian besar berada pada kategori tidak lengkap yaitu sebanyak 72 orang dengan persentase $69 \%$.

Tabel 2. Distriusi Frekuensi Pertumbuhan

Balita di Puskesmas Blang Mangat Kota

Lhokseumawe Tahun 2019

\begin{tabular}{|c|l|c|c|}
\hline No & $\begin{array}{c}\text { Pertumbuhan Balita } \\
\text { Usia 1-5 Tahun }\end{array}$ & Frekuensi & $\begin{array}{c}\text { Persentase } \\
\mathbf{( \% )}\end{array}$ \\
\hline 1. & Gizi Kurang & 63 & 61 \\
2 & Gizi Baik & 41 & 39 \\
\hline \multicolumn{2}{|c|}{ Total } & 104 & 100 \\
\hline
\end{tabular}

Tabel 2 menunjukkan bahwa pertumbuhan balita (1-5 tahun) di Puskesmas Blang Mangta Kota Lhokseumawe tahun 2019, sebagian besar berada pada kategori gizi kurang yaitu sebanyak 63 orang dengan persentase $61 \%$.

Tabel 3. Hubungan Pemberian Imunisasi Dasar dengan Pertumbuhan Pada Balita di Puskesmas Blang Mangat Kota

Lhokseumawe Tahun 2019

\begin{tabular}{|c|c|c|c|c|c|c|c|c|c|}
\hline \multirow[t]{3}{*}{$\begin{array}{c}\text { No } \\
\text {. }\end{array}$} & \multirow{3}{*}{$\begin{array}{c}\text { Pemberian } \\
\text { Imunisasi } \\
\text { Dasar }\end{array}$} & \multicolumn{4}{|c|}{$\begin{array}{c}\text { Pertumbuha } \\
\text { n pada Balita } \\
\text { (1-5 Tahun) }\end{array}$} & \multirow{2}{*}{\multicolumn{2}{|c|}{ Total }} & \multirow{3}{*}{$\left|\begin{array}{c}p- \\
\text { value }\end{array}\right|$} & \multirow{3}{*}{$\alpha$} \\
\hline & & \multicolumn{2}{|c|}{\begin{tabular}{|c|} 
Gizi \\
Kurang
\end{tabular}} & \multicolumn{2}{|c|}{$\begin{array}{c}\text { Gizi } \\
\text { Baik }\end{array}$} & & & & \\
\hline & & f & $\%$ & $\mathbf{f}$ & $\%$ & $\mathbf{N}$ & $\%$ & & \\
\hline $\begin{array}{l}1 . \\
2 .\end{array}$ & $\begin{array}{l}\text { Lengkap } \\
\text { Tidak } \\
\text { Lengkap }\end{array}$ & $\begin{array}{c}4 \\
58\end{array}$ & \begin{tabular}{l|}
13 \\
81
\end{tabular} & $\begin{array}{l}25 \\
13\end{array}$ & $\begin{array}{l}78 \\
18\end{array}$ & $\begin{array}{l}32 \\
72\end{array}$ & $\begin{array}{l}100 \\
100\end{array}$ & 0.002 & 0.05 \\
\hline & Jumlah & 62 & 60 & 38 & 36 & 104 & $\begin{array}{c}10 \\
0\end{array}$ & & \\
\hline
\end{tabular}


Tabel 3 menunjukkan bahwa ada hubungan secara signifikan terhadap pertumbuhan pada balita (1-5 tahun) dengan nilai signifikan $(p)$ sebesar 0.002 yang artinya $p$-value $<0.05$ menyatakan bahwa terdapat hubungan yang signifikan antara pemberian imunisasi dasar dengan pertumbuhan pada balita (1-5 tahun).

\section{PEMBAHASAN}

Dari hasil penelitian yang dilakukan terhadap pemberian imunisasi dasar lengkap di Puskesmas Blang Mangat Kota Lhokseumawe tahun 2019 sebagian besar pada kategori tidak lengkap yaitu sebanyak 72 orang dengan persentase $69 \%$.

Hasil penelitian terdahulu tentang Faktor yang Berhubungan dengan Pemberian Imunisasi Dasar Lengkap pada Bayi yang dilakukan oleh Vivi Triana (2016) di Kecamatan Kuranji dengan jenis penelitian analitik dengan metode cross sectional. Hasil penelitian ini menunjukkan sebagian besar pemberian imunisasi pada kategori tidak lengkap yaitu dengan persentase $47.50 \%$.

Menurut Aziz (2013), imunisasi adalah untuk memberikan kekebalan pada bayi dan anak dengan memasukkan vaksin atau virus yang telah dilemahkan ke dalam tubuh agar tubuh bayi membuat zat anti/tahan untuk mencegah terhadap penyakit tertentu. Manfaat dari pemberian imunisasi ini adalah untuk memberikan perlindungan total dan menyeluruh terhadap penyakit-penyakit yang berbahaya dan sering terjadi pada tahun-tahun awal kehidupan seorang anak.

Dari hasil penelitian pertumbuhan pada balita (1-5 tahun) di sebagian besar berada pada kategori gizi kurang yaitu sebanyak 63 orang dengan persentase $61 \%$.

Hasil dari penelitian terdahulu tentang Hubungan Antara Tingkat Pengetahuan Ibu tentang Tumbuh Kembang Anak yang dilakukan oleh Rohmilia Kusuma (2012) di Wilayah Kerja Puskesmas Penumping Surakarta dengan jenis penelitian analitik dengan pendekatan cross sectional. Hasil penelitian menunjukkan sebagian besar berpengetahuan baik tentang tumbuh kembang anak yaitu sebanyak 39 orang dengan persentase $78 \%$.

Menurut Chomaria (2015), pertumbuhan berkaitan dengan perubahan dalam besar, jumlah, ukuran, dan fungsi tingkat sel, organ maupun individu, yang diukur dengan ukuran berat (gram, pound, kilogram), ukuran panjang (cm, meter), umur tulang dan keseimbangan metabolic (retensi kalsium dan nitrogen tubuh).

Dari hasil penelitian menunjukkan bahwa ada hubungan antara pemberian imunisasi dasar dengan pertumbuhan pada balita (1-5 tahun) dengan nilai $p$-value 0.002 sehingga $p<0.05$, yang berarti bahwa ada hubungan antara pemberian imunisasi dasar dengan pertumbuhan pada balita (1-5 tahun).

Hasil Penelitian yang didapatkan sesuai dengan penelitian terdahulu tentang tentang hubungan pemberian imunisasi dasar 
dengan pertumbuhan pada bayi (0-1 tahun) yang dilakukan oleh Nani Wulan Dari (2016) di Posyandu Desa Sunggal Kecamatan Medan Sunggal dengan jenis penelitian analitik. Hasil penelitian menunjukkan ada hubungan yang signifikan antara pemberian imunisasi dasar lengkap dengan pertumbuhan pada bayi (0-1 tahun) dengan nilai p-value 0.002 .

Menurut Yuniarti (2015), Pemberian imunisasi dasar lengkap juga sangat berpengaruh terhadap proses pertumbuhan dan perkembangan balita. Pertumbuhan dan perkembangan merupakan tahapan yang sangat penting bagi mahkluk hidup yaitu sebagai salah upaya untuk mempertahankan kelangsungan hidup dan mencari keturunan. Pertumbuhan dan perkembangan secara umum memiliki pengertian yang sama akan tetapi secara khusus keduanya sangat berbeda.

Menurut asumsi peneliti, pemberian imunisasi dasar mempunyai hubungan dengan pertumbuhan balita (1-5 tahun) karena pemberian imunisasi dasar bertujuan untuk memberikan kekebalan terhadap antigen/virus tertentu untuk mencegah penyakit dan kematian bayi dan balita. Imunisasi diketahui bahwa sangat erat hubungannya dengan malnutrisi dan penyakit infeksi yang dapat secara langsung mempengaruhi status gizi bayi dan balita dimasa yang akan datang.

\section{KESIMPULAN}

Berdasarkan hasil penelitian ini dapat disimpulkan bahwa 69\% balita di Puskesmas Blang Mangat tidak mendapatkan imunisasi dasar lengkap dan dari angka tersebut balita yang tidak mendapatkan imunisasi dasar lengkap akan mengalami pertumbuhan dan perkembangan yang kurang baik dan akan mengalami gizi kurang.

\section{UCAPAN TERIMA KASIH}

1. Terima kasih kepada Dinas Kesehatan, Puskesmas Blang Mangat Kota Lhokseumawe yang telah memberikan fasilitas pelaksanaan penyuluhan dan penelitian masalah pemberian imunisasi terhadap pertumbuhan balita (1-5 tahun).

2. Terima kasih kepada tim Posyandu dan orang tua balita yang telah berpartisipasi dan membantu selama proses pengumpulan dana dilaksanakan.

\section{REFERENSI}

Anwar, H. (2012). Peranan Gizi dan Pola Asuh dalam Meningkatkan Tumbuh Kembang Anak.

Atikah (2014). Imunisasi dan Vaksinasi. Yogyakarta : Nuha Medika

Aziz, A. (2013). Asuhan Neonatus, Bayi \& Balita. Jakarta : EGC

Chomaria (2015). Panduan Terlengkap Tumbuh Kembang Anak Usia 0-5 Tahun. Surakarta : Hikmah

Depkes, RI, (2013). Buku Kesehatan Ibu dan Anak. Jakarta : Depkes

Dwiastuti, P. \& Prayitno, N. (2012). FaktorFaktor yang Berhubungan dengan Pemberian Imunisasi BCG. Depok : STIKes MH

Dinkes Aceh (2017). Profil Kesehatan Aceh Tahun 2016. Aceh : Dinkes Aceh 
Hanum, M. (2014). Tumbuh Kembang, Status Gizi dan Imunisasi Dasar pada Balita. Yogyakarta : Nuha Medika

Kemenkes, RI. (2015). Antropometri Status Gizi pada Anak. [Internet], Tersedia dalam : http://gizi.depkes.go.id/wpcontent/uploads/.../buku-skantropometri [Diakses 3 Januari 2019]

Kemenkes, RI. (2018). Profil Kesehatan Indonesia 2017. Jakarta : Kemenkes RI

Moersintowarti, B. dkk. (2012). Tumbuh Kembang Anak dan Remaja. Jakarta : Sagung Seto

Notoatmodjo, S. (2014). Metodelogi Penelitian Kesehatan. Jakarta : PT. Rhineka Cipta

Palupi, A.W. (2013). Pengaruh Penyuluhan Imunisasi terhadap Peningkatan Pengetahuan dan Sikap Ibu tentang Imunisasi Dasar Lengkap pada Bayi Sebelum Usia 1 Tahun. Semarang : FK UNS

Ranuh, I. dkk. (2014). Buku Ajar II Tumbuh Kembang Anak dan Remaja. Jakarta : CV. Sagung Seto

Soetjiningsih (2014). Tumbuh Kembang Anak. Jakarta : EGC

Sri Khayati (2014). Hubungan Pemberian Imunisasi Dasar dengan Tumbuh Kembang pada Bayi. Banjarnegara : Fakultas Kesehatan Masyarakat.

Sugiyono (2014). Metodelogi Penelitian. Bandung : Alfa Beta.

WHO (2015). Global Immunization Data. [Internet], Tersedia dalam : http://www.who.int [Diakses 11 Januari 2019].

Wong, D.L. (2013). Buku Ajar Keperawatan Pediatrik. Jakarta : EGC.

Yuniarti (2015). Asuhan Tumbuh Kembang Neonatus, Bayi, Balita dan Anak Pra Sekolah. Bandung : PT. Refika Aditama 